Article

\title{
Sustainable End of Life Management of Crystalline Silicon and Thin Film Solar Photovoltaic Waste: The Impact of Transportation
}

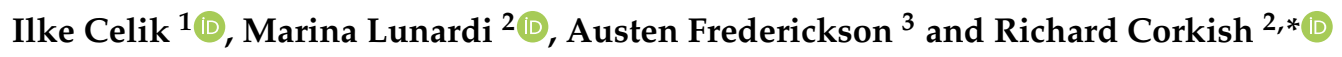 \\ 1 Sustainability and Renewable Energy Systems, Department of Electrical Engineering, University of \\ Wisconsin-Platteville, 1 University Plaza, Platteville,WI 53818,USA; celiki@uwplatt.edu \\ 2 Australian Centre for Advanced Photovoltaics, School of Photovoltaic and Renewable Energy Engineering, \\ UNSW Sydney, Sydney 2052, Australia; m.monteirolunardi@unsw.edu.au \\ 3 Department of Civil and Environmental Engineering, University of Wisconsin-Platteville, \\ 1 University Plaza, Platteville, WI 53818, USA; fredericksoa@uwplatt.edu \\ * Correspondence: r.corkish@unsw.edu.au; Tel.: +61-2-9385-4068
}

Received: 25 June 2020; Accepted: 5 August 2020; Published: 7 August 2020

check for updates

Featured Application: (This article belongs to the Special Issue Advances in Future Energy Materials.) It supports decision-making about the recycling of end-of-life solar modules, particularly elucidating the transport aspects.

\begin{abstract}
This work provides economic and environmental analyses of transportation-related impacts of different photovoltaic (PV) module technologies at their end-of-life (EoL) phase. Our results show that crystalline silicon (c-Si) modules are the most economical PV technology (United States Dollars (USD) 2.3 per $1 \mathrm{~m}^{2} \mathrm{PV}$ module (or $0.87 \mathrm{c} / \mathrm{W}$ ) for transporting in the United States for $1000 \mathrm{~km}$ ). Furthermore, we found that the financial costs of truck transportation for PV modules for $2000 \mathrm{~km}$ are only slightly more than for $1000 \mathrm{~km}$. $\mathrm{CO}_{2 \text {-eq }}$ emissions associated with transport are a significant share of the EoL impacts, and those for copper indium gallium selenide (CIGS) PV modules are always higher than for c-Si and CdTe PV. Transportation associated $\mathrm{CO}_{2-\text { eq }}$ emissions contribute $47 \%$, 28\%, and 40\% of overall EoL impacts of c-Si, CdTe, and CIGS PV wastes, respectively. Overall, gasoline-fueled trucks have 65-95\% more environmental impacts compared to alternative transportation options of the diesel and electric trains and ships. Finally, a hotspot analysis on the entire life cycle $\mathrm{CO}_{2-\mathrm{eq}}$ emissions of different PV technologies showed that the EoL phase-related emissions are more significant for thin-film PV modules compared to crystalline silicon PV technologies and, so, more environmentally friendly material recovery methods should be developed for thin film PV.
\end{abstract}

Keywords: transportation of PV waste; PV end-of-life management; recycling of crystalline silicon PV; recycling of CdTe PV; recycling of CIGS PV

\section{Introduction}

The solar photovoltaic (PV) market is growing quickly, and predictions show that new PV systems installations reached $98 \mathrm{GW}$ in 2019, pushing the cumulative solar capacity to 586GW globally [1]. Considering a circular economy perspective, the improvement in solar energy usage is essential [2-4]. Still, the increase in PV installations creates a substantial amount of new waste, which may account for approximately 8.0 million tons per year by 2030 [5]. Sustainable technologies such as PV depend on the constant progress of their end-of-life (EoL) management [6,7].

Recycling is one of the sustainable EoL management options that adds to the environmental benefits and can further enhance market support for solar energy. Various approaches are available in the 
literature to recycle different PV technologies [6,8-14]. PV Cycle, for example, has a waste management program for solar PV technologies in Europe [15]. In 2016 their process of recycling PV achieved a record recycling rate of $96 \%$ for c-Si PV modules (mass fraction of solids recycled), which surpasses the currently required European Waste Electrical \& Electronic Equipment (WEEE) Directive percentage of recycled fraction. The process begins with the removal of the cables, junction box, and frame from the PV module. Then, the module is shredded, sorted, and separated. The separation of the materials allows them to be sent to specific recycling processes associated with each material. Another example is the full recovery end of life photovoltaic (FRELP) process, which is an industrial-scale process that combines mechanical and chemical approaches that aims to recover 100\% of the materials from the EoL PV modules in an economically viable way $[9,16,17]$. There are also examples of cadmium telluride (CdTe) and copper indium gallium selenide (CIGS) module recycling processes [18-24]. First Solar developed a recycling process for $\mathrm{CdTe}$ modules, which includes management of the collection and transportation of EoL modules to the recycling center [25]. Their process recovers $90 \%$ of the glass for use in new products and $95 \%$ of the semiconductor materials for use in new solar modules. Another example is the pilot project funded by the Japanese Government via the New Energy and Industrial Technology Development Organization (NEDO). Their recycling process can be used for Si or CIS, and it is based on pyrolysis of the polymers (primarily the encapsulant) in a furnace. The process starts with the removal of the frames and the backsheet foil before the thermal process begins. After that, for CIS only, the EVA resin is burned, and the CIS layer is grated. For the c-Si modules, the semiconductor materials are recovered, as is the glass cullet [26].

Recycling of PV modules may create public concerns about hazardous materials in PV modules which can leach to the environment if they are not correctly handled [19,27]. Furthermore, the economic feasibility and adverse environmental impacts of long-distance transportation of PV modules at their EoL is a barrier to market penetration of PV recycling technologies [28], but the literature presents very few studies about the transport-related environmental and economic consequences of PV module recycling. For example, Fthenakis presented a feasibility study for recycling thin-film solar cells, including transportation, and concluded that the small quantities and high transportation costs make PV recycling options relatively expensive [27]. It was also highlighted that PV recycling could be technologically and economically feasible if the processes can improve features such as infrastructure, centralized application for recovered materials, as well as ongoing research. Latunussa et al. [9] published an LCA study following a "gate-to-gate" approach of the FRELP recycling process, including the transportation of the PV modules. Their results showed that of all the considered impact categories, the main contributions are related to the transport of the PV waste to the recycling site (e.g., for climate change, this impact represents $\sim 30 \%$ ). On the other hand, another study, including transportation, published by the Fraunhofer Institute [29], estimated very low impacts from transport for recycling. In this analysis, results showed the relevance of the transport distance, particularly for the photochemical ozone creation and eutrophication potential impacts [30-32].

The studies discussed show that there are different outcomes related to transportation of PV modules depending on their technology, distance from the solar farm to the recycling plant, and other assumptions taken into consideration. With this in mind, it becomes clear that more relevant results in terms of the economic and environmental impacts of transportation are needed to inform the stakeholders in PV EoL management. The novelty of this work is to provide economic and environmental analyses of transportation-related impacts of different solar PV module technologies at their EoL phase, using a methodology that uses consistent assumptions for a systematic evaluation. We analyzed c-Si, CdTe, and CIGS solar modules including recycling processes, transportation, and disposal of materials (waste sludge, or contaminated glass etc.), focusing on the $\mathrm{CO}_{2}$ emission impacts. It is also part of our goal to assess the environmental impacts of different transportation alternatives, considering, truck, diesel or electric train, and ship, to identify the most environmentally friendly transport options. We used the life cycle assessment (LCA) method to calculate the environmental impacts of recycling processes. This analysis is made by collecting and analyzing 
information from the whole product/process life cycle, considering inputs and outputs such as energy, materials, wastes, and emissions [33-35].

\section{Methods}

\subsection{Goal and Scope}

The goal of this study is to assess the transportation associated impacts of waste PV modules from an economical and environmental perspective. For this goal, we assessed the recycling scenarios of c-Si, CdTe, and CIGS PV technologies.

The functional unit of the study is $1 \mathrm{~m}^{2}$ of a PV module. GaBi (version 8) [36] and openLCA [37] software were used for the modeling. EcoInvent [38] and US LCI databases and TRACI [39] impact assessment tool were used. The system boundaries of the study were defined as "end-of-use to grave" which incorporates the transportation from the deployment location to recycling sites and from recycling sites to landfill. In addition, recycling of PV modules and landfilling of the waste materials are considered for the analyses.

\subsection{PV End of Life Management}

\subsubsection{Life Cycle Inventories}

Table 1 summarizes the life cycle inventories of EoL management of c-Si, CdTe, and CIGS PV modules. The EoL management of PV modules consists of transportation, recycling, and disposal phases. We selected trucks fueled by diesel to create a baseline scenario for the transportation of PV wastes. In addition, we modeled the transportation for trucks fueled by gasoline, trains fueled by diesel and by fossil-sourced electricity, and ships. The baseline scenario of the transportation involved $1000 \mathrm{~km}$ of travel distance which is the assumed total distance from the deployment location to the collection point and to the recycling center.

Table 1. The comparison of the inventories for recycling of different photovoltaic (PV) modules (1 $\mathrm{m}^{2}$ of PV panel). c-Si and CdTe recycling incorporate mechanical and chemical based methods while CIGS mostly involves chemical based methods. Transportation is consistent for the technologies, equal to $1000 \mathrm{~km}$.

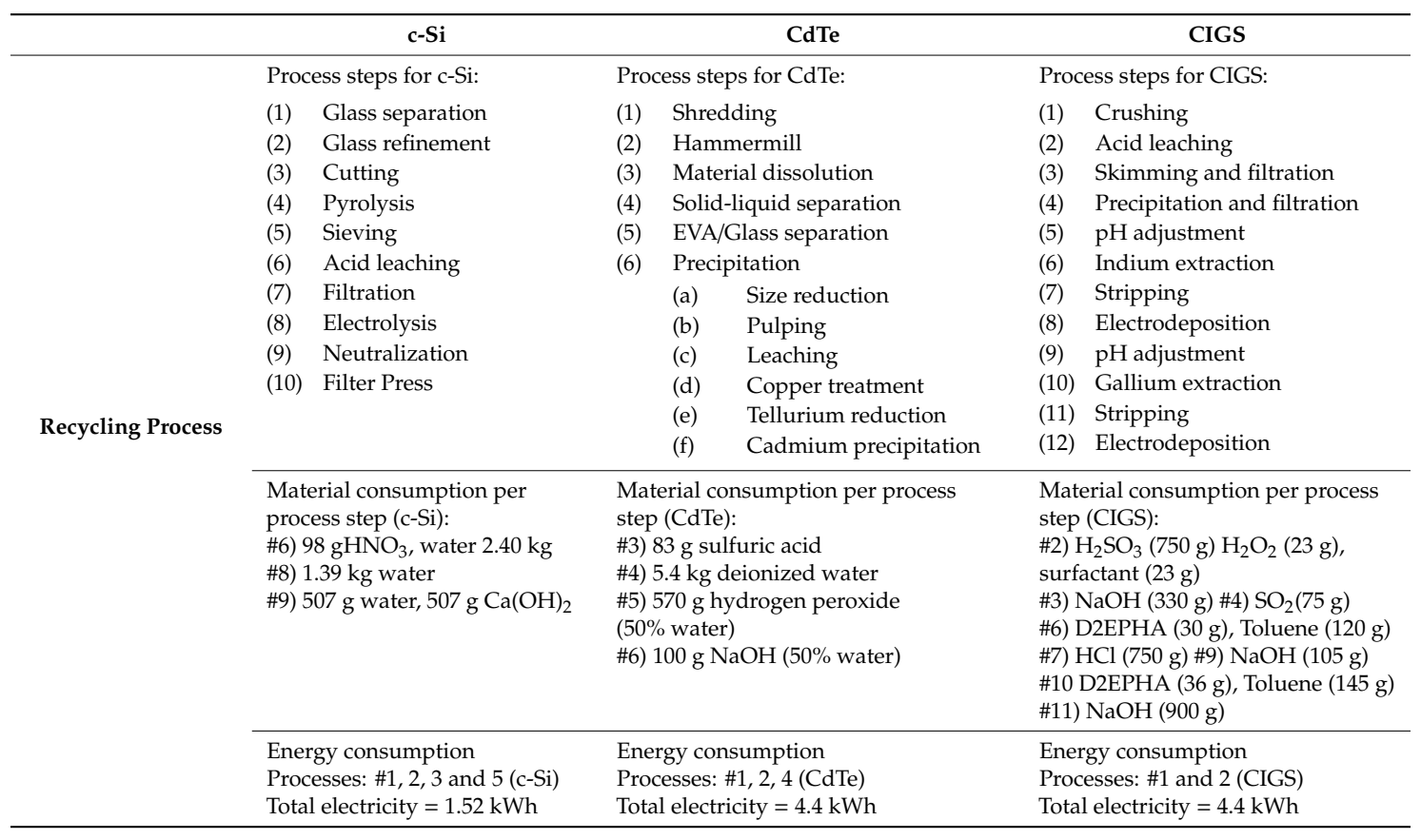


Table 1. Cont.

\begin{tabular}{|c|c|c|c|}
\hline & c-Si & CdTe & CIGS \\
\hline Disposal & $\begin{array}{ll}\text { c-Si: } \\
\text { - } \quad 581 \text { g sludge, containing } \\
\text { metallic residues-disposal } \\
\text { in special landfill } \\
\text { - } \quad 135 \text { g wiring plastic } \\
\text { for incineration) } \\
\text { - } 162 \text { g contaminated glass, } \\
\text { disposed in landfill } \\
\text { - } \\
\text { 3543 g liquid waste, } \\
\text { disposed in landfill }\end{array}$ & $\begin{array}{l}\text { CdTe: } \\
\text { - } \quad 620 \text { g wiring plastic } \\
\text { for incineration } \\
\text { - } 130 \text { g contaminated glass, } \\
\text { disposed in landfill }\end{array}$ & 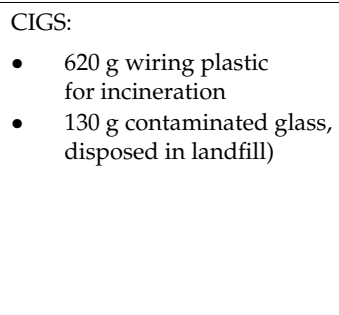 \\
\hline
\end{tabular}

In modeling the environmental impacts c-Si PV modules, we assumed the FRELP [9] method, which combines mechanical and chemical methods required to disseminate, separate, and extract materials from c-Si PVs. The material recovery rates of this method are as follow: $98 \%$ glass, $100 \%$ aluminum, 95\% silicon absorber, $94 \%$ copper, and $94 \%$ silver [9]. In assessing the environmental impacts of thin-film CdTe PVs, we modeled the recycling procedure established and used by First Solar for frameless PV modules. Note that more recent First Solar CdTe modules are manufactured with a frame but an updated inventory for the frame removal is not available at this point. First Solar's industrial recycling technology also incorporates mechanical and acid-based chemical methods. The material recovery rates for the glass and semiconductor in the module are $90 \%$ and $95 \%$, respectively [25,40-42]. In assessing the recycling of CIGS PV modules, we modeled the "innovative recycling" method referred by Rocchetti and Beolchini [22]. This recycling procedure mostly involves chemical methods. This method permits the recycling of glass, EVA, selenium, indium, and gallium materials [19]. Roccehetti and Beolchini did not report the electricity consumption for this method and we assumed that the consumption would be similar to the electricity consumption in the CdTe thin-film recycling.

Materials that cannot be recovered during the recycling of PV panels are sent to landfills at their EoL for disposal. These materials include contaminated glasses that have trace amounts of semiconducting materials, contaminated chemicals that are generated during the recycling process, the sludge that contains metallic residues, plastic materials used in the wiring, encapsulant, backsheet, and sealant of the PV systems. Materials or sludges contaminated by heavy metals need to be sent to special landfills for hazardous waste disposal while the inert wastes are sent to the municipal non-hazardous landfills. Table 1 also summarizes the classification of the materials disposed of after the recycling of c-Si, CdTe, and CIGS PV panels. In modeling the disposal inventories of thin film CdTe and CIGS, we assumed the material composition would be very similar [21] and used the same disposal inventories for both types of PV technologies, as it was referred in First Solar PV recycling facility data [27].

\subsubsection{Cost of Transportation}

In analyzing the cost of transportation in EoL management of PV waste, we used a bottom-up approach to estimate each cost parameter. The cost data for transportation were provided by the logistic and transport industry in the US. The cost of transportation with trucks is USD 1.47 per km for distances longer than $1500 \mathrm{~km}$ and USD 2.55 per $\mathrm{km}$ for distances shorter than $1500 \mathrm{~km}$ in the US. The cost of fuel is also incorporated into the cost analysis as the fuel surcharge, which fluctuates based on the cost of fuel at the time. We use a typical $35 \%$ to accommodate the fuel surcharge because it is based on the average diesel fuel cost in the US over the past several months [43].

To assess the transportation of PV wastes, we calculate how many PV panels a truck can carry considering the weight and the specifications of each PV technology. Note that the environmental impacts from transportation are not affected by these specifications, because the transportation associated impacts are calculated in the LCA databases per metric ton ${ }^{*} \mathrm{~km}$ which affects the impacts 
directly. However, the financial cost of transportation is calculated per $\mathrm{km}$ of a defined type and size of the vehicle. Therefore, additional specifications of PV technologies need to be defined.

Table 2 summarizes the output power and the physical specifications of the PV technologies assessed in this study. The output power information was used to estimate the numbers of PV panels needed for different sizes of PV farms. We made our baseline analysis for a $1 \mathrm{MW}$ solar farm and calculated how the transportation cost varies for a $50 \mathrm{MW}$ and $100 \mathrm{MW}$ solar farm. The surface area and weight of the panel were used to estimate the number of trucks is needed for the transportation of PV panels. In light of this information, we calculated the transportation-associated cost of $1 \mathrm{~m}^{2} \mathrm{PV}$ waste for each technology type.

Table 2. The specifications of the PV technologies.

\begin{tabular}{llll}
\hline Per Module & c-Si [44] & CdTe [45] & CIGS [46] \\
\hline Output [Watt] & 360 & 100 & 160 \\
Surface area $\left[\mathrm{m}^{2}\right]$ & 1.63 & 0.72 & 1.6 \\
Weight $[\mathrm{kg}]$ & 18.6 & 12 & 28 \\
Weight $\left[\mathrm{kg} / \mathrm{m}^{2}\right]$ & 11.4 & 16.6 & 17.5 \\
Volume $\left(\mathrm{m}^{3}\right)$ & 0.075 & 0.058 & 0.104 \\
\hline
\end{tabular}

\section{Results}

\subsection{Cost of Transportation}

The cost calculations of the transportation were performed per unit panel area for each PV technology. We made our analysis using a typical "dry-van" trailer which has approximately $67 \mathrm{~m}^{3}$ of volume. However, with that in mind, the typical gross carry weight of a single truck and trailer is $36,281 \mathrm{~kg}$, with a typical truck and trailer weighing approximately $16,327 \mathrm{~kg}$. That leaves $19,954 \mathrm{~kg}$ (appr. $67 \mathrm{~m}^{3}$ ) of carrying weight/volume within each trailer for each trip. Both volume and weight were used for the calculation to determine the number of modules able to be carried in one trip. The smaller values were chosen as the limiting factors and, consequently, we found that one truck can carry $893 \mathrm{c}-\mathrm{Si}, 1155 \mathrm{CdTe}$, and $644 \mathrm{CIGS}$ PV modules. Using these values, we analyzed how many trucks are needed to carry the waste PV from $1 \mathrm{MW}, 50 \mathrm{MW}$, and $100 \mathrm{MW}$ solar farms that consist of these different PV types (Table 3). As shown in Table 3, the number of trucks required for transportation is not linearly related with the output of the solar farm, which affects the cost of transportation of the waste PV modules.

Table 3. The numbers of truck needed to dissemble different types of PV panels from different sizes of the solar farms.

\begin{tabular}{cccc}
\hline DC Output of the Solar Farms & c-Si & CdTe & CIGS \\
\hline $1 \mathrm{MW}$ & 4 & 9 & 10 \\
$50 \mathrm{MW}$ & 156 & 433 & 486 \\
$100 \mathrm{MW}$ & 312 & 866 & 971 \\
\hline
\end{tabular}

Figure 1 shows the cost of transportation of different PV modules that are disassembled from a $1 \mathrm{MW}$ solar farm while the error bar captures the variations in the transportation cost due to the number of trucks required for 1 to $100 \mathrm{MW}$ solar farms (shown in Table 3). The upper bounds of the error bars equal the cost for disassembling PV modules from a $1 \mathrm{MW}$ solar farm while the lower bounds show the transportation cost of PV panels dismantled from a $100 \mathrm{MW}$ solar farm. 


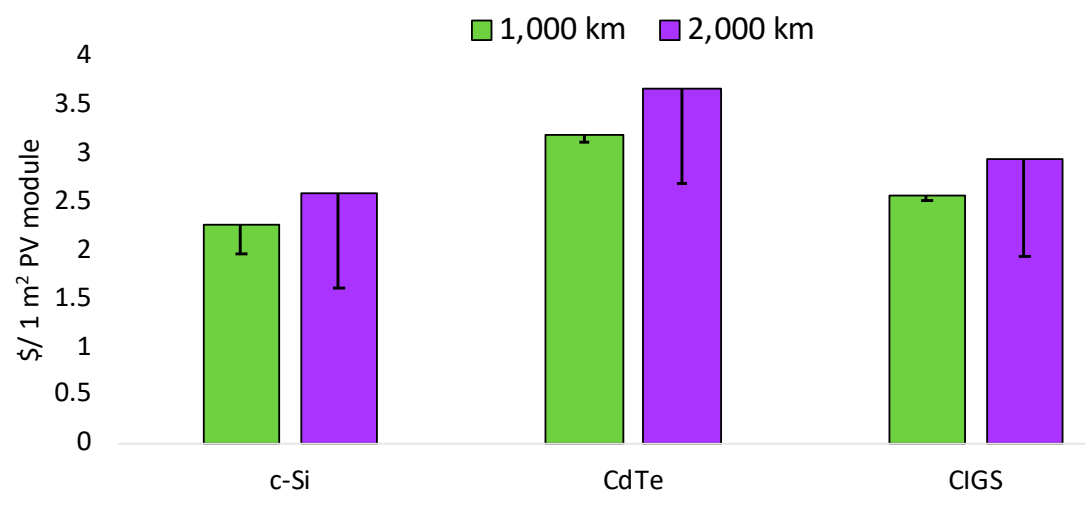

Figure 1. The cost of transportation of different type PV modules with diesel-fueled trucks (note that after $1500 \mathrm{~km}$ the unit cost (USD/km) of truck transportation decreases about 40\%).

Our results show that c-Si modules are the most economical for shipping, mainly because they have the lowest weight per square meter of surface area, primarily due to the assumption of a polymer backsheet for c-Si modules and a glass backsheet for the other two types. Furthermore, the cost of transportation of CdTe modules is about $20 \%-30 \%$ higher than for transportation of CIGS and c-Si PV modules. We also found that the cost of transportation for carrying PV modules by truck for $2000 \mathrm{~km}$ is only $12 \%$ more than for $2000 \mathrm{~km}$. The reason is that as the distance of transportation increases the unit cost of transportation decreases drastically in the US. This brings us to the conclusion that unless the recycling centers are short distances to the installment locations, the cost of transportation between middle distances vs. long distances will be similar. For example, carrying PV modules $1100 \mathrm{~km}$ or $2000 \mathrm{~km}$ is almost similar. This information will be important in arranging the locations of new PV recycling plants in the US.

Lastly, note that we made our analysis considering fully loaded trucks with these different solar panels. As such, we may consider the presented cost values as "minimum" values. Figure 1 shows the cost of transporting $1 \mathrm{~m}^{2}$ of a PV module for $1000 \mathrm{~km}$ is USD 2.3, 3.2, and 2.6 for c-Si, CdTe, and CIGS modules, respectively when the trucks are fully loaded according to the volumes of the PV modules. These cost values will increase if the loads of trucks decreases. We also calculated the average cost of transportation for $\mathrm{\Phi} / \mathrm{W}$ and USD $/ \mathrm{kg}$ PV waste and listed these values in Table 4.

Table 4. Average cost of transportation of different PV technologies.

\begin{tabular}{ccccccc}
\hline & \multicolumn{2}{c}{ c-Si } & \multicolumn{2}{c}{ CdTe } & \multicolumn{2}{c}{ CIGS } \\
\cline { 2 - 7 } & $\mathbf{\phi} / \mathbf{W}$ & $\mathbf{\$} / \mathbf{k g}$ & $\mathbf{d} / \mathbf{W}$ & $\mathbf{d} / \mathbf{k g}$ & $\mathbf{\$} / \mathbf{W}$ & $\mathbf{d} / \mathbf{k g}$ \\
\hline $1000 \mathrm{~km}$ & $0.87 \pm 0.13$ & $10.34 \pm 1.54$ & $2.23 \pm 0.05$ & $16.64 \pm 0.44$ & $2.5 \pm 0.04$ & $13.46 \pm 0.23$ \\
$2000 \mathrm{~km}$ & $1.00 \pm 0.15$ & $11.93 \pm 1.77$ & $2.58 \pm 0.06$ & $19.19 \pm 0.51$ & $2.89 \pm 0.05$ & $15.52 \pm 0.26$ \\
\hline
\end{tabular}

As discussed, the cost of transportation depends on the type of product being transported (and the consequent weight and size). Fthenakis [27] compared the overall costs of landfill disposal with recycling (USD/W) of PV modules, including transportation. This study showed that small quantities and high costs make the recycling option relatively expensive, and that the transportation step represents an approximate additional USD 2.64/module for CdTe modules (varying depending on location and quantity). However, the overall conclusion of his study conclusion is in accordance with our results, which show that low truck loads result in high transportation costs. It is important to highlight that different approaches might be used to calculate the cost of transportation related to the distance between the collection point and the recycling plant, which can be in terms of distance travelled and consequent amount of energy used and time, economic costs etc. [47]. 


\subsection{Environmental Impacts of Transportation}

In analyzing the environmental impacts of transportation, we offered two steps of analysis. First (Figure 2a), we compared the global warming potential (GWP or $\mathrm{kg} \mathrm{CO}_{2 \text {-eq }}$ or carbon footprint) environmental impacts of the most common method of transportation "truck" with other ways of transportation. Second (Figure 2b), we compared the total environmental impacts of four types of transportation methods.
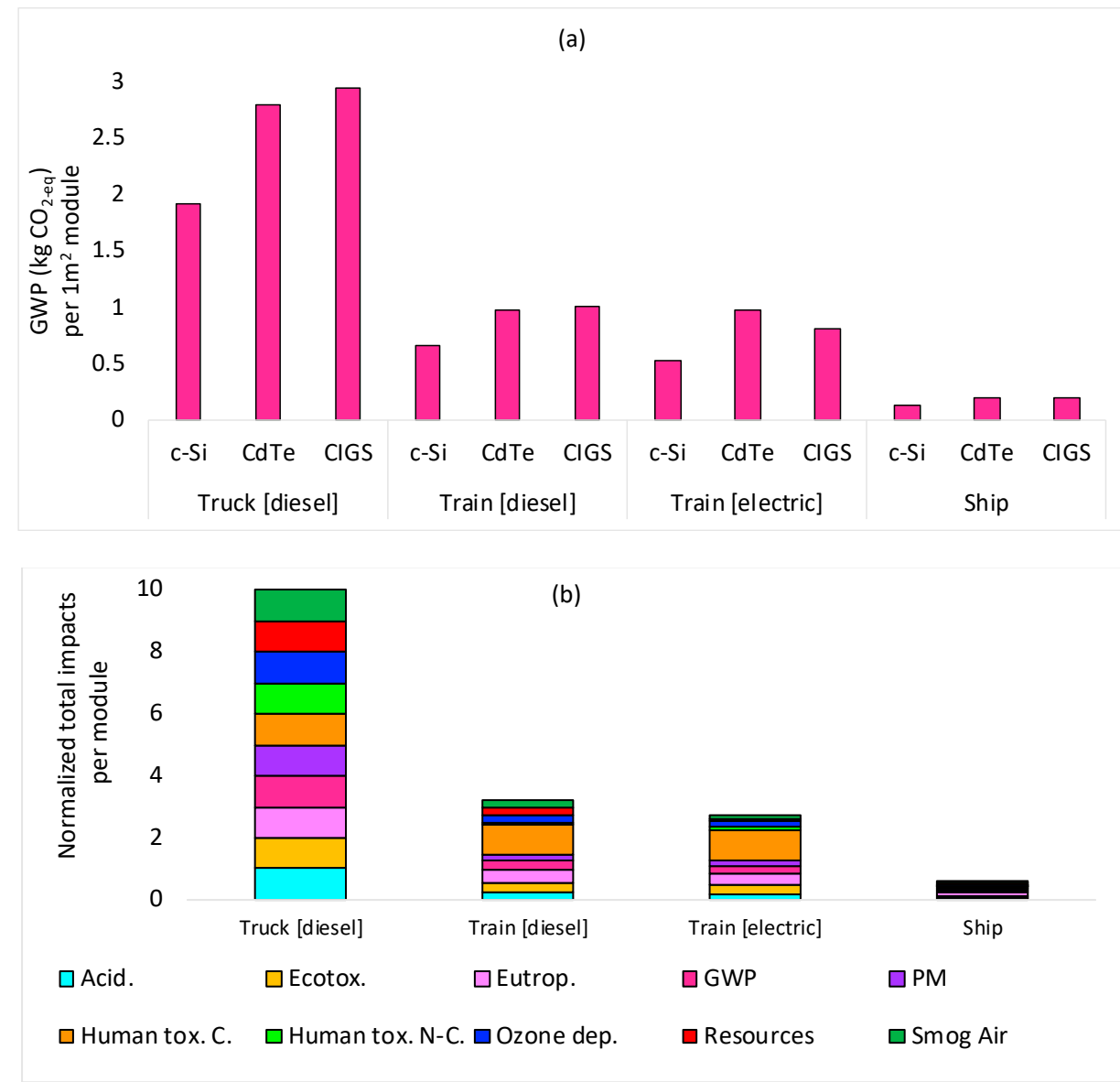

Figure 2. Environmental impacts of transportation of PV module (a) global warming potential (GWP) emissions of transportation (b) total normalized environmental impacts of PV transportation. Note that the calculations for transportation vehicles were performed assuming the average weight of PV module as $20 \mathrm{~kg}$.

Figure 2a shows the GWP impacts of transportation of different PV technologies for $1000 \mathrm{~km}$. As shown, GWP impacts of CIGS modules are always higher than c-Si and CdTe PV modules due to the higher weight of the CIGS modules. Furthermore, using a diesel-fueled truck has the highest GWP impacts among all transportation methods considered here. On the other hand, GWP impacts of shipping have the lowest GWP impacts and are about 15 times less compared to transportation by the diesel-fueled trucks. These results indicate that overseas processing could be an environmentally friendly approach in the recycling of PV waste if we prioritize the GWP impacts from transportation, mainly if the PV plants are located close to or in coastal regions and truck transport to a US port can be minimized.

Figure $2 \mathrm{~b}$ gives a more complete picture of all the environmental impacts related to the transportation of PV waste. For this analysis, we extracted the data for truck, train, and ship transportation from the EcoInvent database Then, we normalized the environmental impacts of 
different transportation options (train with electricity and diesel, and ship) using the diesel-fueled truck as a reference point. To use the impacts of diesel-fueled truck as a reference point for the normalization, we divided each EPA-TRACI impact category for the environmental impacts of all means of transportation options to the those of diesel-fueled trucks assuming each environmental indicator category has equal impact. Thus, we calculated the total normalized environmental impacts of diesel fuel truck's as 10 since there are 10 impact categories in EPA TRACI. The results are somewhat similar to what we observed in the comparison provided in Figure 2a. The total normalized environmental impacts of the diesel-fueled trucks are drastically $(65 \%-95 \%)$ higher compared to the other transportation options. The higher environmental impacts associated with trucks are mostly due to the diesel production $(\sim 40 \%)$ and construction of roads $(\sim 20 \%)$. While the total environmental impacts of trains are more evenly affected by the processes related to train transportation. For example, the impacts from diesel consumption, construction of railway tracks and production of wagons contribute $33 \%, 28 \%$, and $25 \%$ of the total environmental impacts of trains fueled by diesel, respectively. On the other hand, the total impacts of electric trains are mostly due to construction of railway tracks (29\%), production of wagons, and consumption of high voltage electricity (17\%). Most of the environmental impacts of the ship transportation are associated with the emissions due to port activities ( $45 \%)$ and consumption of heavy fuel oils $(\sim 35 \%)$.

The difference between the total environmental impacts correlates with the amount of fuel consumed in each transportation alternative. For example, the trucks consume $37 \mathrm{~g}$ of fuel while the trains consume $2.7 \mathrm{~kg}$ of fuel during the transportation of each metric ton per $\mathrm{km}$. Similarly, diesel train consumes $17 \mathrm{~g}$ of fuel of diesel fuel, while electric train consumes $0.7 \mathrm{~g}$ of fuel and $0.31 \mathrm{MJ}$ of electricity per metric ton per $\mathrm{km}$.

\subsection{A Hotspot Analysis on PV Wastes' EoL}

Figure 3 offers a comparison between the environmental impacts associated with EoL phase of c-Si, CdTe, and CIGS. For each technology, we analyzed the impact of recycling process, transportation, and landfilling (waste sludge, or contaminated glass etc.) of materials.

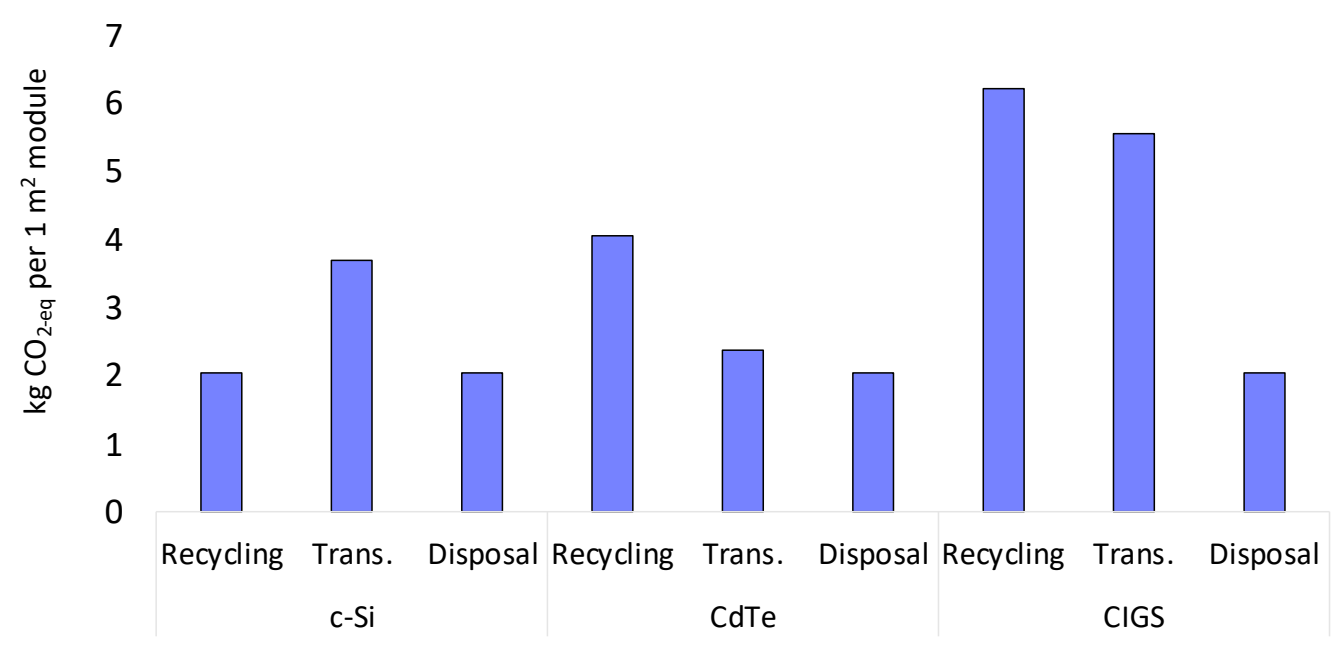

Figure 3. Carbon footprint of PV end-of-life (EoL) management.

Figure 3 indicates that transportation associated $\mathrm{CO}_{2}$ emissions are important in considering the entire EoL phase of different PV technologies. The results show that the CIGS PV module has the highest $\mathrm{CO}_{2 \text {-eq }}$ emissions per $\mathrm{m}^{2}$ of module. This is because the transportation associated emissions are linearly proportional with the mass of the PV panel and PV panels with higher mass per $\mathrm{m}^{2}$ area (given in Table 2) have the highest impacts. For example, about $47 \%$ of the PV EoL management impacts of c-Si technology is contributed by the transportation of PV panels for a total of $1000 \mathrm{~km}$ at their EoL phase, 
e.g., between installation locations and recycling center, and recycling center and landfill. Such a distance can be considered somewhat above of the average transportation distance where the adequate infrastructure and the policies that mandate the recycling exist (e.g., for European countries), it is, on the contrary, far below of realistic transportation distance averages in many countries. For example, the only full-fledged PV recycling center of the US is in Perrysburg, Ohio (northeast of the US) while most of the PV is deployed in Arizona, New Mexico, and California (southwest of the US). The average transportation between these deployment locations to Ohio is $>3000 \mathrm{~km}$. Altering the transportation component analysis performed in Figure 3 using $3000 \mathrm{~km}$ instead of $1000 \mathrm{~km}$ will triple the $\mathrm{CO}_{2}$ emissions and resulted in transportation associated impacts as the dominant GWP source from PV EoL management in the US. In that scenario, disposal of the materials after recycling PV panels contributes $\sim 32 \%$ of the c-Si PV's EoL GWP impacts. After PV materials from panels are recycled, some sludges including heavy metals, liquid wastes that could be considered as inert material, plastic materials that can be incinerated, and contaminated glass particles are generated. All these materials are sent to disposal sites at which they can be treated and/or incinerated and stored. Sludges with a heavy metal content dominate the impacts from disposal $(80 \%)$. The remaining $20 \%$ is contributed from incineration of waste plastic materials from wires, cables, etc., used mainly in the balance of system component of PV panels. Furthermore, we found out that $\sim 30 \%$ of the $\mathrm{CO}_{2}$ emissions associated with the recycling scenario of c-Si PVs can be attributed to the recycling process, mainly from chemical treatment methods. The most impactful contributions to $\mathrm{CO}_{2}$ emissions of the recycling process are from the material separation and extraction processes such as sieving, acid leaching, electrolysis, and neutralization [9].

The total $\mathrm{CO}_{2 \text {-eq }}$ emissions associated with EoL management of thin-film PVs were found to be higher compared to c-Si PV modules. It is mainly due to the higher amount of energy and material consumptions in the recycling process of these thin-film PVs during their EoL management. The recycling related impacts of CIGS are higher than CdTe because of the upstream emissions of the materials required for the recycling process (see the material content in Table 1). The main difference between thin-film recycling and c-Si PV recycling is the extraction of glass from PV panels. In the FRELP method, the glass component of PV modules is separated in the beginning of the recycling process, right after the balance of system (cables, frames, etc.) are taken out, and this separation process is handled by a mixed system involved infra-red heating and high-frequency knives [9]. On the other hand, the recycling of thin-film PVs requires energy-intensive crushing and hammermilling processes in the beginning of the recycling, then glass cullet and metal components are recovered in multiple steps of chemical treatment methods [22,48]. The chemicals and electricity contribute approximately $20 \%$ and $80 \%$ of impacts, respectively, for thin film CIGS and CdTe PVs. The recycling processes are the major contributors of GWP impacts from EoL of thin-films while the impact of transportation varies between $28 \%-40 \%$ of total GWP of thin-films EoL impacts. The impacts of recycling processes of thin-film solar modules have been briefly analyzed in the literature but, due to data uncertainty, a range of results have been published. When comparing disposal, recycling, and transportation of PV panels, one of the most common conclusions is that recycling processes (even including disposal of materials that cannot be recycled) have higher GWP impacts than landfilling the whole PV panel [49]. This conclusion is because recycling processes use considerable quantities of electricity, which are normally from non-renewable sources, which increases the GWP effect compared to landfilling. Additionally, recycling plants are still not as numerous as landfills, so possible additional transportation is considered, also increasing GWP impacts as well [20].

Table 5 provides a comparison between the $\mathrm{CO}_{2 \text {-eq }}$ emissions from EoL management and cradle-to-gate life cycle phases of PV panels. The results show that the EoL scenario for recycling of $1 \mathrm{~m}^{2}$ of a c-Si PV panel resulted in $7.79 \mathrm{~kg}$ of $\mathrm{CO}_{2 \text {-eq }}$ emissions. When the upstream $\mathrm{CO}_{2}$ emissions of c-Si PV modules ( $130 \mathrm{~kg}$ of $\mathrm{CO}_{2 \text {-eq }}$ ) are considered, it is seen that recycling c-Si PV panels at their EoL will contribute less than $10 \%$ of the $\mathrm{CO}_{2 \text {-eq }}$ emissions of the panels' entire life cycle (Table 5). However, the impacts of the EoL phase on the entire impacts of thin film PVs are found to be more significant. 
It can be seen in Table 5 that EoL management of CdTe and CIGS PV modules contributes $13 \%$ and $21 \%$ of the entire life cycle GWP emissions, respectively. Therefore, the thin film PV recycling should be improved with development of more environmentally friendly material recovery methods.

Table 5. The comparison of associated $\mathrm{CO}_{2-e q}$ emissions of entire life cycle of different PV technologies. The contribution of transportation to the total GWP impacts are found to be $\sim 3 \%, 4 \%$, and $9 \%$ for c-Si, CdTe, and CIGS PVs, respectively.

\begin{tabular}{cccc}
\hline & \multicolumn{3}{c}{ GWP Impacts of $\mathbf{1} \mathbf{~ m}^{\mathbf{2}} \mathbf{P V}$ Module $\left(\mathbf{k g ~} \mathbf{C O}_{2-\mathbf{e q}}\right)$} \\
\cline { 2 - 4 } & $\mathbf{c - S i}$ & CdTe & CIGS \\
\hline Cradle-to-Gate $[50,51]$ & 130.2 & 56.3 & 51.4 \\
EoL & 7.79 & 8.51 & 13.85 \\
Total & 137.99 & 64.81 & 65.25 \\
\hline
\end{tabular}

\section{Conclusions}

This study presents financial and environmental analyses for transportation-related impacts of silicon-based, CdTe and CIGS solar photovoltaic modules at their EoL phase. The results from this analysis demonstrate that c-Si modules are the most economical PV technology (USD 2.3 per m2 PV module (or $0.87 \mathrm{~d} / \mathrm{W}$ ) for transporting in the US for $1000 \mathrm{~km}$. Additionally, it was found that there is not much difference (only 12\%) in the cost of transportation for carrying Si-based, CdTe, or CIGS PV modules for either $1000 \mathrm{~km}$ or $2000 \mathrm{~km}$ using trucks. The similarities are related to the relationship between distance and unit cost of transportation in the US, which is non-proportional (higher distances result in lower unit costs of transportation). An important finding from the assessment conducted is that, considering the assumptions made, the $\mathrm{CO}_{2 \text {-eq }}$ emissions associated with transporting $\mathrm{PV}$ modules are lower for c-Si and CdTe than for CIGS because of the higher weight of the CIGS modules. We also found that the transportation associated $\mathrm{CO}_{2 \text {-eq }}$ emissions contribute $47 \%, 28 \%$, and $40 \%$ of overall EoL impacts of c-Si, CdTe, and CIGS PV wastes, respectively. Besides, it was found that, comparing the different types of fuel used for the transportation and considering all the impacts analyzed, using ships (consumes heavy fuel oil) is the most environmentally friendly alternative (considering acidification, ecotoxicity, eutrophication, global warming, particulate matter, human toxicity, and ozone depletion potential) among the alternatives of diesel-fueled trucks and diesel or electricity fueled trains. Finally, a hot spot analysis on the entire life cycle $\mathrm{CO}_{2 \text {-eq }}$ emissions of different PV technologies showed that the EoL phase-related emissions are more significant for thin-film PV modules compared to crystalline silicon PV technologies, so more environmentally friendly material recovery methods should be developed.

Author Contributions: Conceptualization, I.C., M.L. and R.C.; methodology, I.C.; software, I.C.; validation, I.C. and R.C.; formal analysis, I.C.; investigation, I.C. and M.L.; data curation, I.C. and A.F.; writing-original draft preparation, I.C., M.L. and A.F.; writing-review and editing, I.C., M.L., A.F. and R.C.; project administration, I.C. and R.C.; funding acquisition, R.C. All authors have read and agreed to the published version of the manuscript.

Funding: This research was partly funded by the Australian Renewable Energy agency, grant number SRI-001 and the SAIF and URSCA grants provided by Office of Research and Sponsored Programs at the University of Wisconsin-Platteville.

Conflicts of Interest: The authors declare no conflict of interest. The funders had no role in the design of the study; in the collection, analyses, or interpretation of data; in the writing of the manuscript, or in the decision to publish the results. 


\section{References}

1. Nhede, N. Eight Trends Shaping 2019 Global Solar PV Marke. Smart Energy International. 16 April 2019. Available online: https://www.smart-energy.com/renewable-energy/eight-trends-shaping-2019-global-solarpv-market/ (accessed on 10 November 2019).

2. Celik, I.; Song, Z.; Cimaroli, A.J.; Yan, Y.; Heben, M.J.; Apul, D. Life Cycle Assessment (LCA) of perovskite PV cells projected from lab to fab. Sol. Energy Mater. Sol. Cells 2016, 156, 157-169. [CrossRef]

3. Celik, I.; Phillips, A.B.; Song, Z.; Yan, Y.; Ellingson, R.J.; Heben, M.J.; Apul, D. Environmental analysis of perovskites and other relevant solar cell technologies in a tandem configuration. Energy Environ. Sci. 2017, 10, 1874-1884. [CrossRef]

4. Celik, I. Eco-design of Emerging Photovoltaic (PV) Cells. Ph.D Thesis, The University of Toledo, Toledo, OH, USA, 2018.

5. International Revewable Energy Agency (IRENA). End of Life Management-Solar Photovoltaic Panels; International Revewable Energy Agency (IRENA): Bonn, Germany, 2016; ISBN 978-92-95111-99-8. Available online: https://www.irena.org/publications/2016/Jun/End-of-life-management-Solar-PhotovoltaicPanels (accessed on 23 June 2020).

6. Müller, A.; Wambach, K.; Alsema, E. Life cycle analysis of solar module recycling process. Mater. Res. Soc. Symp. Proc. 2006, 895, 89-94. [CrossRef]

7. Maani, T.; Celik, I.; Heben, M.J.; Randall, J. Environmnetal impacts of recycling crystalline silicon (c-Si) and cadmium telluride (CdTe) solar panels. Sci. Total Environ. 2020, 735, 138827. [CrossRef] [PubMed]

8. Dias, P.; Javimczik, S.; Benevit, M.; Veit, H.; Bernardes, A.M. Recycling WEEE: Extraction and concentration of silver from waste crystalline silicon photovoltaic modules. Waste Manag. 2016, 57, 220-225. [CrossRef]

9. Latunussa, C.E.L.; Ardente, F.; Blengini, G.A.; Mancini, L. Life Cycle Assessment of an innovative recycling process for crystalline silicon photovoltaic panels. Sol. Energy Mater. Sol. Cells 2016, 156, 101-111. [CrossRef]

10. Bruton, T.M.; Scott, R.D.W.; Nagle, J.P.; Man, M.C.M.; Fackeral, A.D. Recycling of high value, high energy content components of silicon PV-modules. In Proceedings of the 2th European Photovoltaics Conference, Amsterdam, The Netherlands, 11-15 April 1994.

11. Lunardi, M.; Alvarez-Gaitan, J.; Bilbao, J.; Corkish, R. Comparative Life Cycle Assessment of End-of-Life Silicon Solar Photovoltaic Modules. Appl. Sci. 2018, 8, 1396. [CrossRef]

12. Dias, P.; Schmidt, L.; Gomes, L.B.; Bettanin, A.; Veit, H. Recycling Waste Crystalline Silicon Photovoltaic Modules by Electrostatic Separation. J. Sustain. Metall. 2018, 4, 176-186. [CrossRef]

13. Kang, S.; Yoo, S.; Lee, J.; Boo, B.; Ryu, H. Experimental investigations for recycling of silicon and glass from waste photovoltaic modules. Renew. Energy 2012, 47, 152-159. [CrossRef]

14. Padoan, F.; Altimari, P.; Pagnanelli, F. Recycling of end of life photovoltaic panels: A chemical prospective on process development. Sol. Energy 2019, 177, 746-761. [CrossRef]

15. PV Cycle Breakthrough in PV Module Recycling. Available online: http://www.pvcycle.org/press/ breakthrough-in-pv-module-recycling/ (accessed on 1 March 2018).

16. Ramon, V. FRELP. 16 November 2015. Available online: https://frelp.info/category/news/press/ (accessed on 31 May 2020).

17. Ramon, L. Recupero Integrale Dei Pannelli FV: Il Progetto FRELP. Available online: https://rienergia. staffettaonline.com/articolo/34403/Recupero+integrale+dei+pannelli+FV:+il+progetto+FRELP/Ramon (accessed on 2 June 2020).

18. Berger, W.; Simon, F.-G.; Weimann, K.; Alsema, E.A. A novel approach for the recycling of thin film photovoltaic modules. Resour. Conserv. Recycl. 2010, 54, 711-718. [CrossRef]

19. Grand View Research, Inc., Market Research Report. Solar Panel Recycling Market Analysis, by Process, (Thermal, Mechanical, and Laser), by Type (Monocrystalline, Polycrystalline, and Thin Film), by Region, and Segment Forecasts, 2014-2025; Grand View Research, Inc., Market Research Report: San Francisco, CA, USA, 2017; Available online: https://www.giiresearch.com/report/grvi572909-solar-panel-recycling-market-analysis-byprocess.html (accessed on 23 June 2020).

20. Shibasaki, M.; Niels, W.; Springer, J.; Lombardelli, S. Recycling of thin-film solar modules. Life cycle assessment case study. In Proceedings of the 21st European Photovoltaic Solar Energy Conference, Dresden, Germany, 4-8 September 2006. 
21. Marwede, M.; Berger, W.; Schlummer, M.; Mäurer, A.; Reller, A. Recycling paths for thin-film chalcogenide photovoltaic waste-Current feasible processes. Renew. Energy 2013, 55, 220-229. [CrossRef]

22. Rocchetti, L.; Beolchini, F. Recovery of valuable materials from end-of-life thin-film photovoltaic panels: Environmental impact assessment of different management options. J. Clean. Prod. 2015, 89, 59-64. [CrossRef]

23. Held, M. Life cycle assessment of CdTe module recycling. In Proceedings of the 24th European Photovoltaic Solar Energy Conference, Hamburg, Germany, 21-25 September 2009; pp. 21-25.

24. Savvilotidou, V.; Antoniou, A.; Gidarakos, E. Toxicity assessment and feasible recycling process for amorphous silicon and CIS waste photovoltaic panels. Waste Manag. 2017, 59, 394-402. [CrossRef]

25. Sinha, P.; Cossette, M.; Ménard, J.-F. End-of-life CdTe PV recycling with semiconductor refining. In Proceedings of the 27th EU PVSEC, Frankfurt, Germany, 24-28 September 2012.

26. Komoto, K. Developments on PV Recycling in Japan. In Proceedings of the 24th European Photovoltaic Solar Energy Conference, Amsterdam, The Netherlands, 22-26 September 2014.

27. Fthenakis, V.M. End-of-life management and recycling of PV modules. Energy Policy 2000, 28, 1051-1058. [CrossRef]

28. Deng, R.; Chang, N.L.; Ouyang, Z.; Chong, C.M. A techno-economic review of silicon photovoltaic module recycling. Renew. Sustain. Energy Rev. 2019, 109, 532-550. [CrossRef]

29. Held, M. LCA screening of a recycling process for silicon based PV modules. PV Cycle Conf. 2013, 1-19.

30. Frisson, L.; Lieten, K.; Bruton, T.M.; Declercq, K.; Szlufcik, J.; de Moor, H.; Goris, M.; Benali, A.; Aceves, O. Recent improvements in industrial PV module recycling. In Proceedings of the 16th European Photovoltaic Solar Energy Conference, Glasgow, UK, 1-5 May 2000.

31. Komoto, K.; Lee, J.S.; Zhang, J.; Ravikumar, D.; Sinha, P.; Wade, A.; Heath, G. End-of-Life Management of Photovoltaic Panels: Trends in PV Module Recycling Technologies; Report IEA-PVPS T12-10:2018; International Energy Agency, Photovoltaic Power Systems Program: Paris, France, 2018; ISBN 9783906042619.

32. Stolz, P.; Frischknecht, R. Life Cycle Assessment of Current Photovoltaic Module Recycling; Report IEA-PVPS T12-13:2018; International Energy Agency, Photovoltaic Power Systems Program: Paris, France, 2017; ISBN 9783906042695.

33. Celik, I.; Mason, B.E.; Phillips, A.B.; Heben, M.J.; Apul, D.S. Environmental Impacts from Photovoltaic Solar Cells Made with Single Walled Carbon Nanotubes. Environ. Sci. Technol. 2017, 51, 4722-4732. [CrossRef]

34. Celik, I.; Philips, A.B.; Song, Z.; Yan, Y.; Ellingson, R.J.R.J.; Heben, M.J.M.J.; Apul, D. Energy Payback Time ( EPBT ) and Energy Return on Energy Invested (EROI) of Perovskite Tandem. IEEE J. Photovolt. 2018, 8, 305-309. [CrossRef]

35. Owens, J.W. Life-Cycle Asssesssment-Constraints on Moving from Inventory to Impact Assessment. J. Ind. Ecol. 1997, 1, 37-49. [CrossRef]

36. PE International, GaBi Software v. 8. 2013. Available online: https://www.gabi-software.com/ (accessed on 6 August 2020).

37. Ciroth, A. OpenLCA ICT for the environment in lifecycle applications openLCA-A new open source software for life cycle assessment. Int. J. Life Cycle Assess. 2007, 12, 209-210. [CrossRef]

38. Wernet, G.; Bauer, C.; Steubing, B.; Reinhard, J.; Moreno-Ruiz, E.; Weidema, B. The ecoinvent database version 3 (part 1): Overview and methodology. Int. J. Life Cycle Assess. 2016, 21, 1218-1230. [CrossRef]

39. Bare, J. TRACI 2.0: The tool for the reduction and assessment of chemical and other environmental impacts 2.0. Clean Technol. Environ. Policy 2011, 13, 687-696. [CrossRef]

40. Sinha, P. PV Recycling Policies and Technology. In IEA PVPS Workshop, Proceedings of the 6th World Conference on Photovoltaic Energy Conversion, Kyoto, Japan, 23-27 November 2014.

41. Ravikumar, D.; Sinha, P.; Seager, T.P.; Fraser, M.P. An anticipatory approach to quantify energetics of recycling CdTe photovoltaic systems. Prog. Photovolt. Res. Appl. 2016, 24, 735-746. [CrossRef]

42. First Solar the Recycling Advantage. Available online: www.firstsolar.com/recycling (accessed on 22 June 2020).

43. Team Run Smart. What Is Your Fuel Surcharge Worth? Team Run Smart: Fort Mill, NC, USA, 2013; Available online: https://www.teamrunsmart.com/articles/truck-smart/fuel/january-2013/what-is-your-fuelsurcharge-worth (accessed on 31 May 2020).

44. SunPower. SunPower X-Series-Residential-Solar-Panels. 2019. Available online: https://us.sunpower.com/sites/ default/files/media-library/data-sheets/sunpower-x-series-residential-solar-panels-x22-360-datasheet514618-revc.pdf (accessed on 23 June 2020). 
45. First Solar Technical Document-Series -4. Available online: http://www.firstsolar.com/-/media/First-Solar/ Technical-Documents/Series-4-Datasheets/Series-4-Datasheet.ashx (accessed on 23 June 2020).

46. XSun. XSun-Brochure. Available online: https://xsunx.com/pdf/CIGSBrochure-draft.pdf (accessed on 23 June 2020).

47. Rodrigue, J.-P.; Notteboom, T. Transport Cost and Rates. Available online: https://transportgeography.org/ ?page_id=5268 (accessed on 6 August 2020).

48. Cyrs, W.D.; Avens, H.J.; Capshaw, Z.A.; Kingsbury, R.A.; Sahmel, J.; Tvermoes, B.E. Landfill waste and recycling: Use of a screening-level risk assessment tool for end-of-life cadmium telluride (CdTe) thin-film photovoltaic (PV) panels. Energy Policy 2014, 68, 524-533. [CrossRef]

49. Vellini, M.; Gambini, M.; Prattella, V. Environmental impacts of PV technology throughout the life cycle: Importance of the end-of-life management for Si-panels and CdTe-panels. Energy 2017, 138, 1099-1111. [CrossRef]

50. Briese, E.; Piezer, K.; Celik, I.; Apul, D. Ecological network analysis of solar photovoltaic power generation systems. J. Clean. Prod. 2019, 223, 368-378. [CrossRef]

51. Ecoinvent v.3.1. Available online: http://www.ecoinvent.org/ (accessed on 1 January 2016).

(C) 2020 by the authors. Licensee MDPI, Basel, Switzerland. This article is an open access article distributed under the terms and conditions of the Creative Commons Attribution (CC BY) license (http://creativecommons.org/licenses/by/4.0/). 